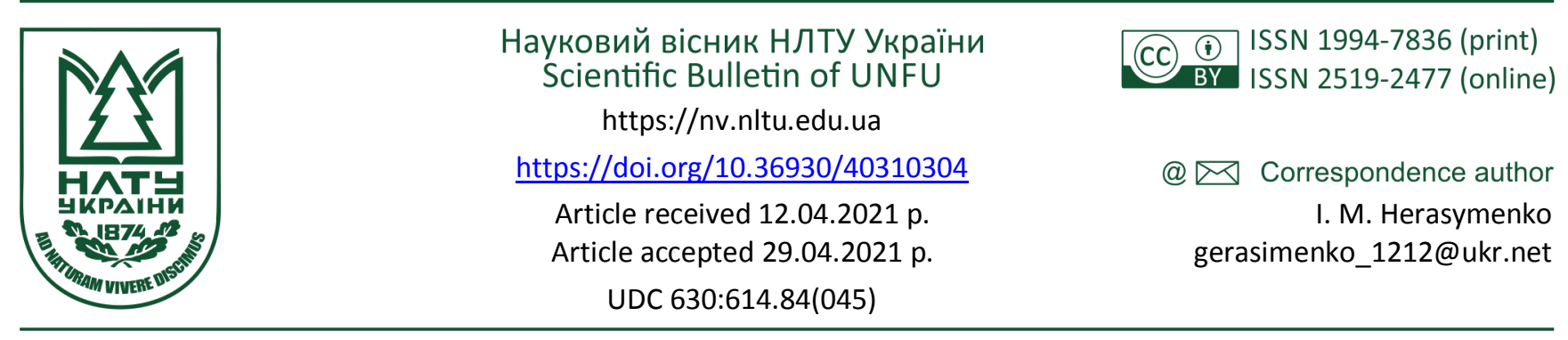

І. М. Герасименко, О. О. Соловйова, С. В. Пронь

Національний авіаційний університет, м. Київ, Украӥна

\title{
ПЕРСПЕКТИВНІ НАПРЯМИ БОРОТЬБИ З ПОЖЕЖАМИ У ЛІСОВОМУ ГОСПОДАРСТВІ УКРАЇНИ
}

\begin{abstract}
Проаналізовано сучасний стан лісового фонду України, внаслідок чого виявлено райони з найбільшою та найменшою лісистістю. Найбільші лісові масиви розташовані в Поліссі та Карпатах. Досліджено, що найбільшою загрозою для лісових масивів є пожежі, які залишаються серйозною проблемою через значну кількість випадків і знищення площі в багатьох областях. Проаналізувавши статистичні дані пожеж в Україні, виявлено райони, де зареєстровано найбільшу кількість лісових пожеж. З'ясовано, що своєчасне виявлення лісових пожеж дає змогу запобігати їх розповсюдженню на великі території і знищенню великих площ лісових масивів. Доведено, що авіація на сьогодні є одним 3 найефективніших засобів раннього виявлення та гасіння лісових пожеж. Запропоновано формування гнучкої системи раннього дистанційного виявлення осередків лісових пожеж на базі сучасних безпілотних авіаційних систем, які стануть доповненням до наявних авіаційних пілотованих систем, наземних систем та систем космічного моніторингу, що дасть змогу постійно відстежувати лісопожежну ситуацію. Унаслідок застосування цих систем під час патрулювання лісових масивів відбувається забезпечення швидкої інформаційної підтримки керівника гасіння лісової пожежі для визначення тактичних прийомів і технічних способів боротьби 3 вогнем, а також оперативного прийняття протипожежних заходів, стосовно певної ситуації.
\end{abstract}

Ключові слова: авіація; моніторинг; спостереження; пожежогасіння; безпілотні літальні апарати; взаємодія.

\section{Вступ}

Вогонь загрожував людям з моменту його появи на Землі, і так само довго людство намагається знайти захист від нього. Уміння користуватися вогнем дало людині відчуття незалежності від циклічної зміни тепла та холоду, світла і темряви. Водночас, пожежі завдають величезного матеріального збитку і часто супроводжуються загибеллю людей.

Виникнення пожеж, як техногенних, так і природних, пов'язане $з$ двома основними чинниками - антропогенними і природними. Антропогенні чинники можна враховувати і контролювати, а природні умови можна тільки враховувати, оскільки контролю вони не піддаються. Погодні умови мають вирішальне значення для поширення пожежі. Дощі і висока вологість обмежують і припиняють горіння, сильні вітри сприяють поширенню вогню. Тиха погода і знижена температура повітря особливо в нічний час стабілізують горіння i знижують його інтенсивність. Суха спекотна погода створює найсприятливіші умови для виникнення і поширення вогню [4].

Жахлива статистика світових пожеж не оминає і Україну. Клімат в Україні змінюється досить швидко, а в південній частині країни він наближається до грецько- го. Підвищені температури, теплові хвилі і суха погода роблять рослинність легкозаймистою і призводять до сильних і некерованих пожеж. Зокрема, щорічно виникає значна кількість надзвичайних ситуацій природного та техногенного характеру, у структурі яких вагоме місце належить пожежам, зокрема і природного походження. Дослідження є актуальними, тому що за останні роки проблема збереження лісів від вогню набула особливої гостроти через підвищення температури повітря, відсутність опадів та сильні вітри [4].

Об'єкт дослідження - пожежна небезпека лісового господарства України.

Предмет дослідження - прикладні підходи до оцінювання рівня пожежної небезпеки лісового господарства України.

Мета роботи - запропонувати способи ефективного спостереження та моніторингу за станом пожежної безпеки лісового фонду України, що дасть змогу своєчасно виявляти лісові пожежі та запобігти їх розповсюдженню у надзвичайних ситуаціях.

Для досягнення зазначеної мети визначено такі основні завдання дослідження:

- здійснити аналіз сучасного стану лісового фонду України;

- проаналізувати причини виникнення та динаміку кількості лісових пожеж в регіонах України;

Інформація про авторів:

Герасименко Ірина Миколаївна, канд. екон. наук, доцент, кафедра організації авіаційних робіт і послуг.

Email: iryna.herasymenko@npp.nau.edu.ua; https://orcid.org/0000-0002-4297-3973

Соловйова Олена Олександрівна, канд. екон. наук, професор, кафедра економіки та бізнес-технологій. Email: olena.soloviova@npp.nau.edu.ua; https://orcid.org/0000-0002-7089-0067

Пронь Світлана Віталіївна, канд. техн. наук, доцент, кафедра організації авіаційних робіт і послуг. Email: svitlana.pron@npp.nau.edu.ua; https://orcid.org/0000-0002-1177-9588

Цитування за ДСтУ: Герасименко І. М., Соловйова О. О., Пронь С. В. Перспективні напрями боротьби з пожежами у лісовому господарстві України. Науковий вісник НЛТУ України. 2021, т. 31, № 3. С. 27-33.

Citation APA: Herasymenko, I. M., Soloviova, O. O., \& Pron, S. V. (2021). Some prospective directions of fire fighting in Ukraine's forests. Scientific Bulletin of UNFU, 31(3), 27-33. https://doi.org/10.36930/40310304

Науковий вісник НЛТУ України, 2021, т. 31, № 3

Scientific Bulletin of UNFU, 2021, vol. 31, no 3 
- запропонувати способи та методи проведення спостереження та моніторингу стану лісового фонду України.

Наукова новизна отриманих результатів дослідження - вперше запропоновано метод взаємодії декількох безпілотних літальних апаратів для здійснення моніторингу лісових масивів для боротьби з пожежами до, під час та після пожежі, що забезпечує економію часу в разі виявлення пожеж.

Практична значущість результатів дослідження можуть бути використані для розроблення ефективних заходів зі своєчасного виявлення та боротьби $з$ лісовими пожежами в регіонах України.

Аналіз останніх досліджень та публікацій. Питання, пов'язані з проблематикою лісових пожеж, висвітлено у працях Ю. О. Абрамова, А. М. Грішина, Г. О. Дорpepa, Е. В. Конєва, М. П. Курбатського, Л. М. Куценка, О. П. Созніка, Л. А. Суханова, О. А. Тарасенка, Г. П. Тєліцина та інших.

Основну увагу в їх дослідженнях приділено параметрам займання, самозайманню, горінню елементів дерева; процесам поширення полум'я лісовою підстилкою та кронами дерев; впливам на пожежну небезпеку різноманітних природних та антропогенних чинників, таких як рельєф місцевості, кліматично-погодні умови та людська діяльність тощо.

Методи та системи виявлення осередків лісових та інших ландшафтних пожеж описано в наукових працях учених: В. Яцківа, А. Кузика, В. Поповича, В. Товарянського, Р. Покровського, В. Комяка, Ю. Стародуба, П. Урсуляка, В. Шевчука, В. Богомолова. Розробки в галузі протипожежного моніторингу лісових масивів запропоновано у працях А. Д. Кузика, Т. Є. Рака, О. О. Смотр, О. М. Гусак, Я. І. Виклюка, Е. Chuvieco, Ү. Н. Chen, J. Li, G. X. Peng, G. L. Hufford, H. L. Kelley, R. K. Moore, J. S. Cotterman, A. Lavrov, Yasar Guneri Sahin, J. L. Dupuy, P. Vachet, J. Marechal, J. Melendez, de Castro A. J., M. Mutlu, S. C. Popescu, K. G. Zhao, K. Bouabdellah, H. Noureddine, Larbi S. F. Frau та інших.

Проблеми сучасного стану та розвитку методів дистанційного зондування Землі, що забезпечують можливість оцінити характеристики стану лісового покриву, висвітлено у наукових працях В. В. Зуйка, А. М. Козуба [8], В. Е. Михалевича, М. П. Слободяника [6], Н. О. Суворової, В. М. Чернявського.

Однак питання своєчасного виявлення, моніторингу та спостереження за станом лісових масивів висвітлено недостатньо та потребують постійного вдосконалення. Актуальним залишається питання формування гнучкої системи охорони лісу, здатної постійно відстежувати лісопожежну ситуацію в регіонах України.

\section{Результати дослідження та їх обговорення}

Загальна площа лісових ділянок, які належать до лісового фонду України, становить 10,4 млн га, зокрема вкриті лісовою рослинністю 9,6 млн га. Загалом лісистість України - 15,9\%, однак країна посідає 9 місце серед європейських країн за цим показником. Запаси деревини оцінюють в межах 2,1 млрд м ${ }^{3}$. За рік в Україні приростає 35 млн м ${ }^{3}$ деревини. Умови для лісовирощування в Україні неоднорідні, тому ліси поширені по території держави нерівномірно (рис. 1).

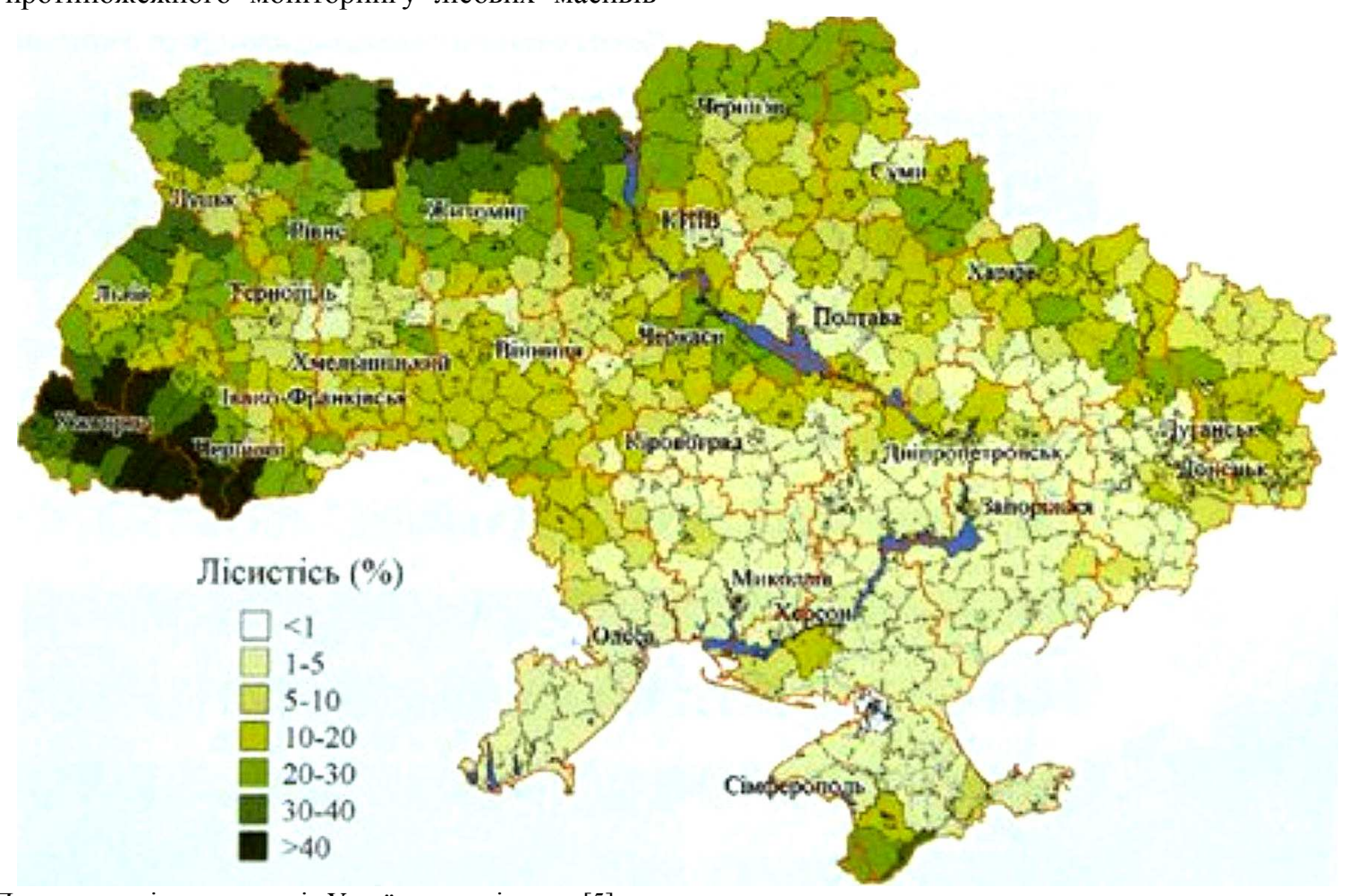

Рис. 1. Поширення лісових масивів України за регіонами [5]

Лісистість змінюється від 3,7 \% у Миколаївській області до 50,8 \% в Закарпатській. У лісовому фонді мають перевагу цінні хвойні та твердолистяні породи. Найбільші лісові масиви розташовані в Поліссі та Карпатах. Насадження хвойних порід займають 43 \% від загальної площі, 3 них сосна - $33 \%$. Твердолистяні становлять $43 \%$, з них дуб і бук - $32 \%$. Особливістю лісів нашої країни $є$ те, що здебільшого вони складаються 3 молодняка, питома вага якого становить 45,3 \%. Всього промислових лісів в Україні - 8,6 млн га, запаси деревини - 2 млрд м $^{3}$.

У лісах України пожежі є небезпечними та призводять до значних збитків. Вони залишаються серйозною проблемою через велику кількість випадків і площ, які 
вони пошкоджують в багатьох областях. За останні 40 років на всій території України в середньому за рік виникало від 792 до 6743 пожеж, а площа становила від 286 до 14691 га (рис. 2).

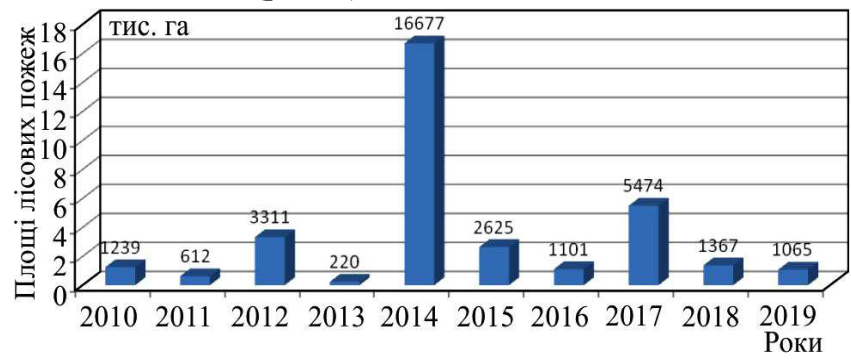

Рис. 2. Площі лісових пожеж в Україні за 2010-2019 рр. [5]

Дані рис. 2 свідчать про наявність систематичних підйомів та спадів площі лісових земель, пройдених вогнем. Збитки, яких завдають пожежі лісовому господарству, значно перевищує збитки від шкідливих комах i хвороб лісу, разом узятих. Лісові пожежі послаблюють життєдіяльність насаджень, які в подальшому впливають на масове розмноження шкідливих об'єктів і захворювань.

У 2019 р. в лісах України ліквідовано 1261 пожежу на площі 1065 га, зокрема верхових - 52 га. Збитки від лісових пожеж становлять 6,7 млн грн (рис. 3).

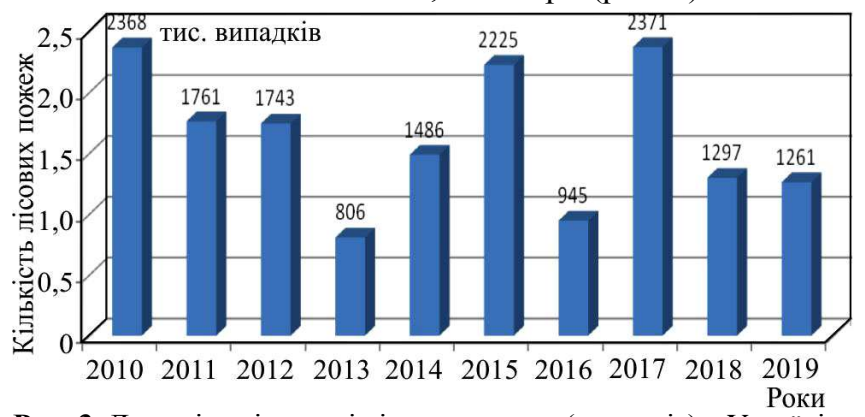

Рис. 3. Динаміка кількості лісових пожеж (випадків) в Україні за 2010-2019 pp. [5]

Найбільшу кількість пожеж зареєстровано у Херсонському (166 випадків), Дніпропетровському (142), Харківському (113), Луганському (110) та Чернігівському (102) обласних управліннях лісового та мисливського господарства. Найбільша площа пожеж у Житомирському (175 га), Херсонському (169), Чернігівському (158) та Одеському (128) обласних управліннях.

У 2019 р. сталося 12 лісових пожеж з площею понад 5 га, зокрема [5]:

• ДП " Ізмаїльський лісгосп" Одеської області - 63,7 га:

- ДП "Остерський лісгосп" Чернігівської області - дві пожежі площею 65,4 га та 15,5 га;

- ДП "Білокоровицький лісгосп" Житомирської області - дві пожежі загальною площею 24,9 га;

- ДП "Овруцький спецлісгосп" Житомирської області - 15 га;

- ДП "Овруцький лісгосп" Житомирської області - 11,5 га;

- ДП "Попільнянський лісгосп" Житомирської області 15,5 га;

• ДП "Радомишльське ЛМГ" Житомирської області - 27 га;

- ДП "Петриківський лісгосп" Дніпропетровської області 23,9 га;

- ДП "Свалявський лісгосп" Закарпатської області - 16,5 га;

- ДП "Бердянський лісгосп" Запорізької області - 8 га.

Проблема виникнення лісових пожеж за останні роки привертає до себе особливу увагу в контексті зменшення площ лісів світу, що є наслідком пожежі. Відновлення одного гектара хвойного лісу коштує приблизно 300 \$ США. Для відновлення 1 га згорілого лісу потрібно висадити від 3 до 5 тис. саджанців. Точна кількість рослин залежить від природних умов і параметрів грунту [7]. Від швидкості виявлення лісової пожежі залежить ефективність його гасіння та кількість ресурсів, які витрачаються на пожежні заходи.

Своєчасне виявлення лісових пожеж дає змогу запобігати їх розповсюдженню у надзвичайних лісопожежних ситуаціях. Лісовій пожежі легше запобігти, ніж іiі ліквідувати, оскільки вогонь у лісі розповсюджується стихійно з великою швидкістю. Так, за швидкості поширення вогню по фронту 3 м/хв, за сприятливих умов зовнішнього середовища площа лісової пожежі через 2 год після виникнення пожежі може зрости в 10 разів, а периметр - в 1,2 раза.

На відміну від сільськогосподарських культур, ліс росте дуже повільно. Новий ліс, якщо не відбудеться нових пожеж, зможе піднятися на згарищах не раніше ніж через 80-100 років. Щоб виростити одне покоління лісу, повинні працювати, змінюючи один одного, як мінімум три покоління працівників лісничих.

Хоча в Україні і намагаються серйозно боротися 3 пожежами, але через нестачу засобів та коштів, невчасне реагування та гасіння вогню повністю вирішити проблему не вдається.

Особлива загроза від пожеж існує в Чорнобильській зоні через міграції радіонуклідів із димом і попелом на значну відстань та повторного зараження прилеглих територій [1]. На період початку 2020 р. вже було зафіксовано декілька масштабних лісових пожеж в Чорнобильській та Житомирській зонах. За попереднім оцінюванням, площа пожеж становила 11500 га. Було залучено 2 літаки та 3 гвинтокрили ДСНС. Використання авіації було залучено з першого дня. Проблема відсутності на державному рівні адекватної міжвідомчої системи охорони лісів, торфовищ, інших природних ландшафтів наразі $\epsilon$ істотною проблемою для країни. Чорнобильська зона є джерелом потенційної небезпеки, як і для України, так і для сусідніх держав та спираючись на події, які відбулись, маємо висновок, що контроль цих двох територій відіграє важливу роль у роботі спеціального авіаційного загону оперативно-рятувальної служби цивільного захисту ДСНС України.

Переважна більшість від загальної кількості пожеж в Україні припадають на найбільш пожежонебезпечні хвойні ліси, в основному соснові молодняки та середньовікові деревостани.

Частота виникнення загорянь у лісі, хоча і визначається погодними та лісорослинними умовами, але посилення такого чиннику, як наявність джерел вогню, icтотно підсилює загрозу. Тому на окремих територіях тенденції виникнення та площі пожеж можуть суттєво відрізнятися навіть за подібних природних і погодних умов. Здебільшого основною причиною виникнення займань у лісі $є$ антропогенний чинник. Через необережне поводження 3 вогнем людей у лісі, випалювання сухої трави, спалювання сміття на прилеглих територіях і навіть підпали проблема 3 пожежами є дуже гострою. Але завдяки детальному вивченню цього питання та його особливостей можливо зменшити збитки від пожеж, а також на підставі цього мінімізувати ймовірність як їх виникнення, так і пошкодженої площі.

Для запобігання виникненню пожеж може сприяти покращення прогнозування та вдосконалення організації лісопожежної безпеки. Неналежний контроль на 
певних лісових територіях і їхня віддаленість від протипожежних служб часто призводять до значної кількості та площі пожеж, а також великих економічних та екологічних збитків. Отже, лісові пожежі спричиняють прямі та непрямі матеріальні збитки. До прямих збитків лісового господарства від лісових пожеж належать втрати внаслідок зниження продуктивності і товарності деревостанів, а також витрати на проведення післяпожежних санітарних рубок лісу та лісовідновлення згарищ. Непрямі збитки складаються із втрат від зменшення ефективності виконання протиерозійної, водорегулювальної, полезахисної, кліматичної, санітарно-гігієнічної та рекреаційної функцій лісу. Це особливо важливо в лісах біля великих міст і підприємств.

Необхідною умовою забезпечення рівня протипожежного захисту лісів, що відповідає сучасним соціально-економічним вимогам, є формування гнучкої системи охорони лісу, здатної постійно відстежувати лісопожежну ситуацію, що безперервно змінюється у кожному регіоні України, і регулювати свою структуру, параметри і режими робіт відповідно до цієї ситуації.

До сучасних методів ефективного спостереження та моніторингу за рівнем пожежної безпеки лісового фонду України належать методи дистанційного зондування. Сучасний стан розвитку методів дистанційного зондування забезпечує можливість оцінити стан лісового покриву і створити систему регіонального моніторингу лісів на підставі комбінованого використання даних різного просторового розрізнення [6]. Також важливим $є$ метод інформування Державної системи протипожежного захисту лісів у разі виявлення осередку пожежі під час здійснення авіаційних польотів.

Доповнити сучасні авіаційні пілотовані системи, наземні системи, системи космічного моніторингу під час виконання патрулювання лісових масивів здатна система раннього дистанційного виявлення осередків лісових пожеж на базі наявних сучасних безпілотних авіаційних систем, які здатні здійснювати допоміжний протипожежний моніторинг лісів [2].

Основне завдання застосування цих систем під час виконання патрулювання лісових масивів - забезпечення інформаційної підтримки керівника гасіння лісової пожежі для визначення тактичних прийомів і технічних способів боротьби з вогнем. А також оперативного прий. няття протипожежних заходів, стосовно виниклої ситуації, а саме:

- визначення точних координат лісової пожежі;

- напрямки його поширення, площі, виду, інтенсивності;

- наявності природних перешкод для поширення вогню;

- особливостей рослинності лісу, рельєфу місцевості, водних джерел;

- місць відходу підрозділів у разі загрозливої небезпеки.

Для економії часу при виявлені пожеж, у цій роботі пропонуємо розглянути взаємодію декількох безпілотних літальних апаратів (БПЛА) під час патрулювання лісових масивів.

Взаємодія декількох БПЛА має багато можливостей при використанні на лісових пожежах. Наприклад, різний парк БПЛА може обстежити різні регіони України в одні і ті самі терміни, дозволяючи встановлювати черговість спостереження відповідної важливості або ризику регіону. Різні типи БПЛА можуть відігравати різну роль. Наприклад, тактичні БПЛА або міні-БПЛА можуть застосовуватися для підтвердження і точного виз- начення місцезнаходження сигналу тривоги за допомогою БПЛА з великою висотою і високою витривалістю. Окрім цього, дані, зібрані різними БПЛА, можуть використовуватися для підтвердження пожежної тривоги, а отже, підвищувати надійність системи. Наприклад, автоматичне виявлення лісових пожеж, виявлення джерела сигналу небезпеки уражень, визначення об'єкта підпалу через людську діяльність й інше. Дуже високий коефіцієнт помилкових сигналів небезпеки може бути відкинуто, використовуючи дані з різних джерел.

Можливе застосування команди малих БПЛА (низька висота, коротка витривалість) для спільного моніторингу шляху поширення великих лісових пожеж. Підхід полягає у використанні декількох недорогих різнотипних БПЛА, які будуть взаємодіяти у виконанні скоординованих дій для виявлення і моніторингу пожеж.

Усі завдання зі спостереження за пожежами можуть бути розбиті на такі етапи: пошук пожежі; підтвердження пожежі; спостереження за пожежею; постпожежний етап. Завдання дуже схожі на операції з виявлення пожежі, які виконують на сьогодні служби пожежогасіння 3 використанням пілотованого літального апарату.

Традиційно для пожежогасіння використовують три основні платформи: наземні системи, системи повітряних засобів та супутникові системи. Ці платформи, як і раніше, мають різні технологічні та практичні проблеми в разі їх використання в оперативних умовах, таких як недолік надійності, витрати та інші. Для боротьби 3 лісовими пожежами інтеграція цих систем з БПЛА дає багато можливостей, дозволяючи реалізовувати рішення багаторівневих і багаторазових підходів (рис. 4).

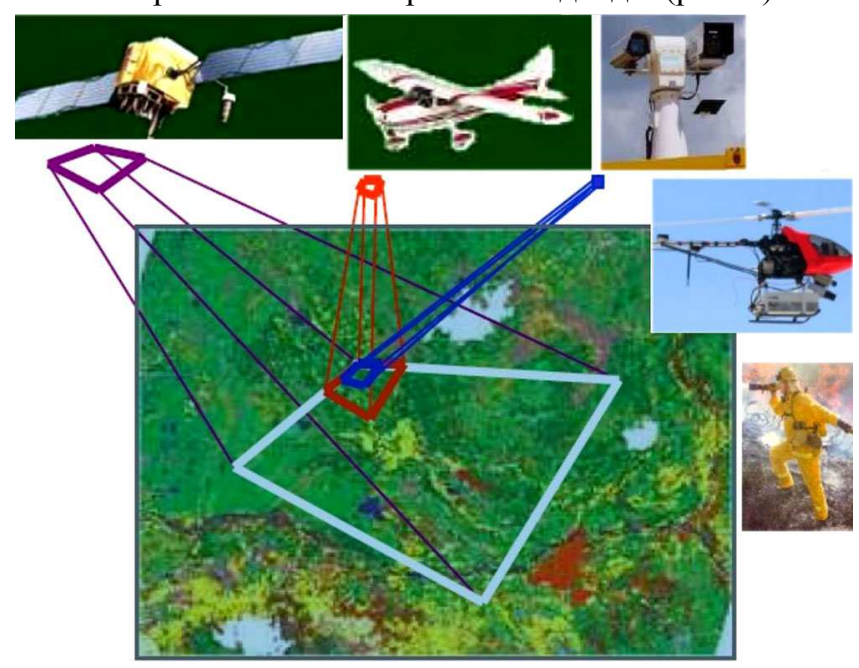

Рис. 4. Багаторівневі і багаторазові рішення у боротьбі з лісовими пожежами

Далі подано короткий огляд застосування вже перевіреного і можливого застосування БПЛА для боротьби 3 лісовими пожежами за схемою до - під час - після пожежі.

Можливість застосування БПЛА перед пожежею. Найактуальніші заходи до пожежогасіння - це спостереження за лісом, створення карт пожежонебезпеки, моніторинг рослинності і створення тривимірних рослинних карт 3 давачами сканування. Ці завдання широко виконуються супутниками. Пілотовані повітряні судна використовуються зі значними витратами для деталізації відображення. Незважаючи на те, що супутникові системи спостереження довели свою цінність у великих і однорідних областях, їх основним недоліком $є$ те, що 
просторові і тимчасові дані, які вони отримують, є недостатніми для деяких видів діяльності.

Деякі застосовувані сьогодні БПЛА підходять для цього завдання завдяки високій витривалості і великому корисному навантаженню, здатних нести потужні давачі спостереження. Ці БПЛА придатні для створення карт пожежонебезпеки (ризики пожежі) і гідрічних стрескарт. Окрім цього, невеликі і бюджетні БПЛА можуть також використовуватися для локальної топографічної зйомки (відображення) з високою роздільною здатністю, яке може бути придатним на спеціальних охоронних територіях, а також для сприяння розвитку і вивчення діяльності при лісових пожежах.

Окрім цього, метод об'єднання даних з декількома роздільними здатностями може використовуватися для поширення супутникових даних, об'єднавши їх 3 даними вищої роздільної здатності, зібраних з БПЛА. Більш того, зображення і дані, надані з БПЛА, можуть використовуватися для обстеження і виявлення потенційно небезпечних видів діяльності в лісах. Під час патрулювання кожен БПЛА застосовує автоматичні методи оброблення зображень.

Потенційні застосування БПЛА під час пожежі. Найпоширеніші традиційні автоматичні системи виявлення пожежі засновані на наземних системах. Існують деякі автоматичні системи виявлення лісових пожеж, які виконують виявлення диму з візуальними (оптичними) камерами. Ці системи мають недоліки, такі як покриття і відсутність надійності автоматичного виявлення в умовах навколишнього середовища, що змінюється. Використання БПЛА можуть чітко подолати ці недоліки 3 можливостями, починаючи 3 автоматичного виявлення, підтвердження чіткої локалізації пожеж до моніторингу та вимірювання пожежі.
Незважаючи на те, що супутникові системи застосовувалися для автоматичного виявлення пожежі та моніторингу, затримка виявлення і низька роздільна здатність супутникових даних, як і раніше, є істотними недоліками. БПЛА можуть надавати дані $з$ вищою частотою і роздільною здатністю. Окрім цього, тактичні БПЛА і невеликі бюджетні БПЛА можуть використовуватися для підтвердження і локалізації сигналу небезпеки, а також для моніторингу пожежі, у ближній зоні.

БПЛА, які підходять для виявлення пожежі, повинні володіти високою здатністю витривалості. Отже, БПЛА 3 фіксованим (нерухомим) крилом є такими, що відповідають вимогам застосування для виявлення пожеж. Окрім цього, для виконання моніторингу, БПЛА можуть зависати в бажаному положенні і можуть використовуватися для отримання докладного зображення пожежі. А також БПЛА можуть автоматично отримати місце розташування пожежного фронту і відправити його в центр управління з боротьби з пожежами.

Дані, отримані 3 наземної станції, прив'язані до геолокації. Для диспетчера пожежної сигналізації в центрі дистанційного керування тривалість оброблення від збирання даних на борту БПЛА, за допомогою супутникової лінії зв'язку, оброблення файлів даних зображень 3 географічною прив'язкою, становить менше години.

Під час недавнього експерименту вчені змогли передати теплові дані в управління пожежами всього за 10 хвилин, з використанням супутникових ліній зв'язку (рис. 5). Під час виконання патрулювання кожен БПЛА використовує автоматичну обробку виявлення пожежі. БПЛА виконує сегментацію вогнищ пожежі в інфрачервоних зображеннях, а також виконує виявлення пожежі за допомогою теплового давача.

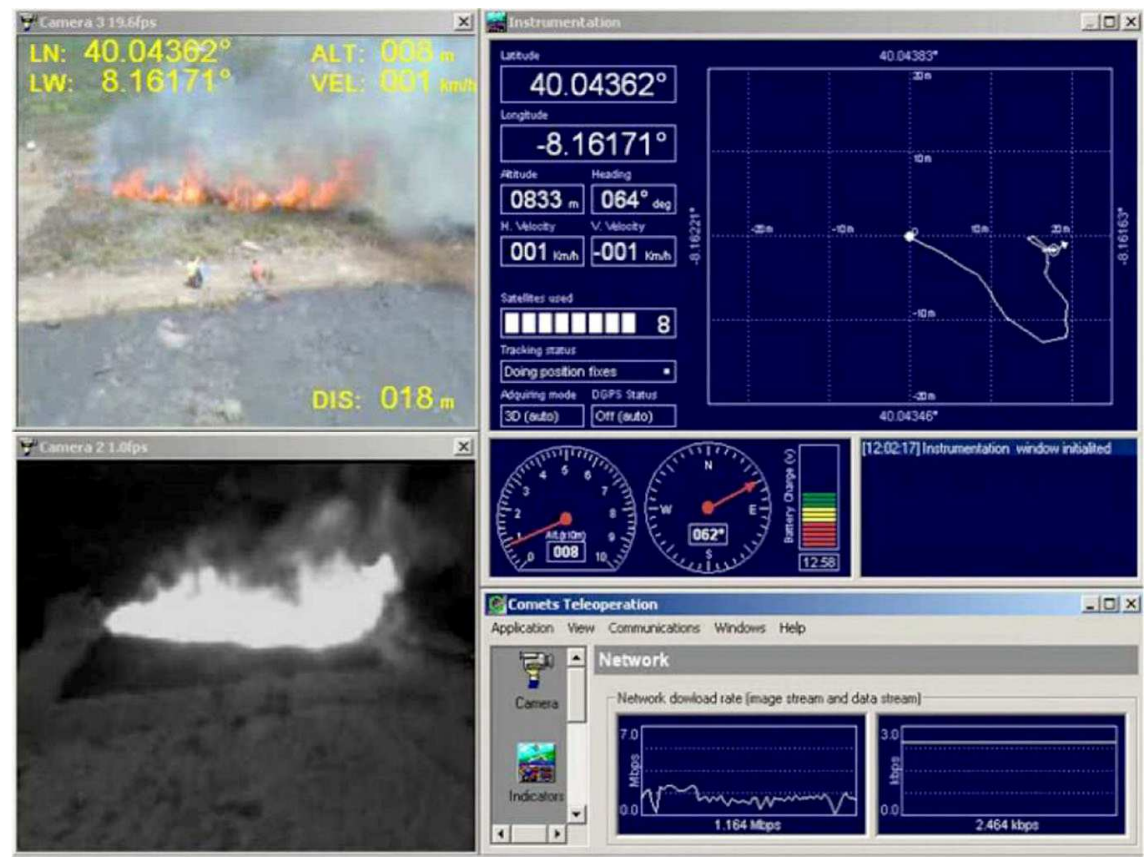

Рис. 5. Дані, отримані під час проведення пожежного експерименту з БПЛА [3]

Якшо надійшов сигнал пожежі, центр управління розробляє завдання на політ, а БПЛА, який виявив вогнище спалаху, дається команда перебувати поблизу пожежі на безпечній відстані. БПЛА за допомогою давачів відправляються для підтвердження сигналу тривоги. Решта БПЛА відправляються для підтвердження тривоги за допомогою їх давачів. Методи спільного виявлен- ня пожежі містять об'єднані результати від БПЛА. Якщо виявлено, що сигнал тривоги помилковий, моніторинг лісу відновлюється. Якщо отримано підтвердження сигналу тривоги, тоді починається етап моніторингу пожежі. БПЛА отримують наказ, знаходиться поблизу району пожежі для синхронного отримання чіткого зображення пожежі з різних ракурсів. 
Зображення стабілізуються в режимі реального часу, використовуючи встановлену схему (рис. 6,a), яке було знято з БПЛА на етапі спостереження за пожежею. За допомогою отриманих зображень, використовуючи алгоритми сегментації пожежі, можна визначити параметри розвитку вогню з зазначеним осередком пожежі (див. рис. 6,б).
Спільно дієві способи застосовуються для поліпшення оцінки поширення фронту вогню (рис. 7). Ще однією важливою функцією БПЛА є ретрансляція зв'язку. Пожежа може статися в місці, де відсутня інфраструктура комунікацій. БПЛА може перебувати поблизу на великій висоті, виступаючи в ролі ретранслятора для різних комунікаційних систем.
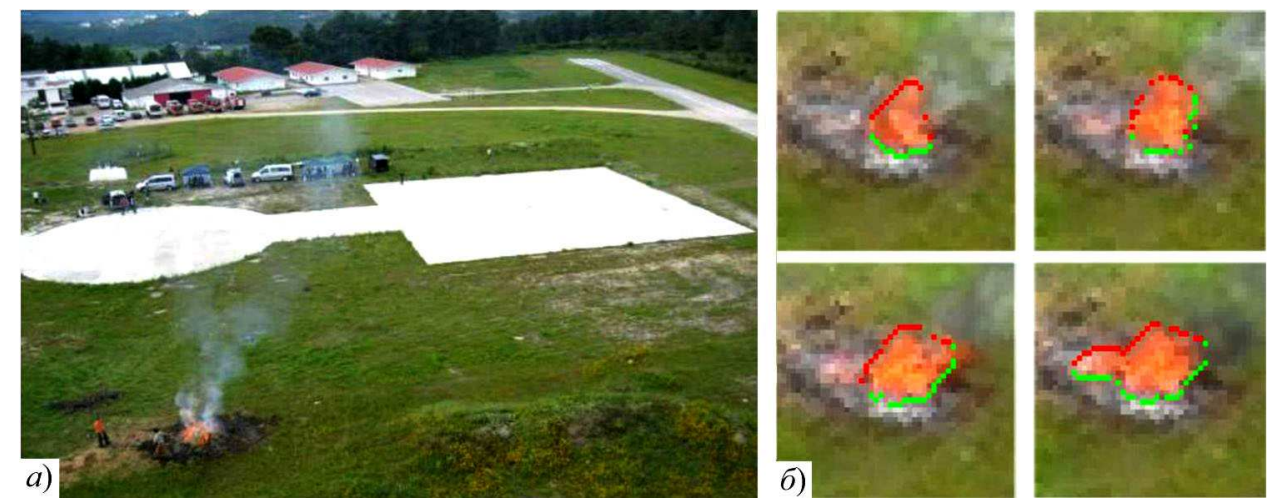

Рис. 6. Відстеження пожежі з використанням БПЛА $(a)$, послідовне зображення розвитку джерела пожежі, отримане автоматично (б)

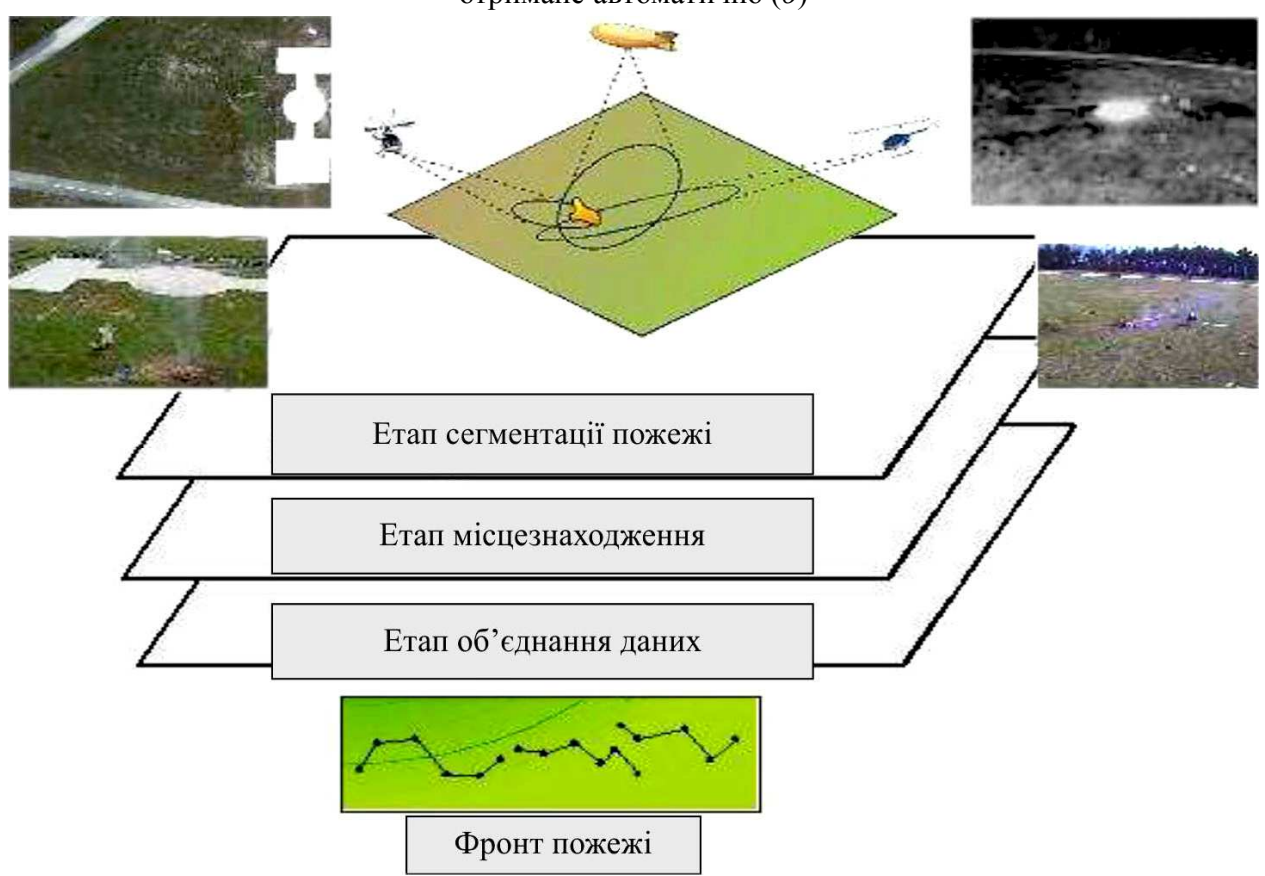

Рис. 7. Спільні дії під час моніторингу пожеж

Можливе застосування БПЛА після пожежі. БПЛА можуть використовуватися також для аналізу ситуації після пожежі, для виявлення присутності активних вогненних згарищ. Ще одним завданням, яке виконується на цьому етапі, є відображення спаленої області. Можуть застосовуватися різні технології для аерофотозйомки високої роздільної здатності від БПЛА.

\section{Висновки}

Проаналізовано сучасний стан лісових масивів регіонів України. Особливістю лісів нашої країни є те, що здебільшого вони складаються з молодняка, питома вага якого становить 45,3\%. Всього промислових лісів в Україні - 8,6 млн га, запаси деревини - 2 млрд м ${ }^{3}$.

Досліджено статистичні дані кількості пожеж в Україні та виявлено райони, де зареєстровано найбільшу кількість лісових пожеж.

Запропоновано доповнити наявні авіаційні пілотовані системи, наземні системи, системи космічного моні- торингу сучасними безпілотними авіаційними системами для виконання моніторингу лісових масивів, що дасть змогу вчасно дистанційно виявляти осередки лісових пожеж у регіонах України.

\section{References}

1. Azarov, S. I., Yeremenko, S. A., Sydorenko, V. L., Smirnova, O. M., Biloshytskyi, M. V., Vlasenko, Ye. A., Pruskyi, A. V., Sereda, Yu. P., \& Volianskoho, P. B. (Ed.). (2016). Naukovi zasady zakhystu naselennia i terytorii vid naslidkiv lisovykh pozhezh z radiatsiino nebezpechnymy faktoramy. Monohrafiia. Kyiv: TOV "Interdruk", 203. Retrieved from; https://lg.nmc.dsns.gov.ua/files/2019/9/14/NAUKOVI_ZASADI.pdf

2. Husak, O. M. (2017). Informatsiina tekhnolohiia rannoho vyiavlennia oseredkiv lisovykh pozhezh. Visnyk Lvivskoho derzhavnoho universytetu bezpeky zhyttiediialnosti, 15, 33-38. [In Ukranian].

3. Martines-de-Dios molodshyi, Merinos, L., Kabaliero, F., \& Ollero, A. (2011). Avtomatychne vymiriuvannia lisovoi pozhezhi za dopomohoiu nazemnykh stantsii ta bezpilotnykh povitrianykh system. Datchyky, 11(6), 6328-6353. https://doi.org/10.3390/s110606328 
4. Prostorovyi analiz vplyvu klimatychnykh zmin na pozhezhnu bezpeku v Ukraini. (2021). Retrieved from; https://nuczu.edu.ua/images/topmenu/science/vseukrainskij-konkurs-studencheskikh-nauchnikh-rabot-s-oblastej-znanij-i-spetsial-nostej/pb21/9.pdf

5. Publichnyi zvit derzhavnoho ahentstva lisovykh resursiv Ukrainy. (2019). Retrieved from; https://mepr.gov.ua/files/images/news_2020/26022020/PUBLIChNII20ZVIT20DALRU20ZA20201920RIK.pdf

6. Slobodianyk, M. P. (2014). Vykorystannia metodiv DZZ ta HIStekhnolohii dlia monitorynhu lisovykh resursiv. Visnyk heodezii ta kartohrafii, $1, \quad 27-31 . \quad$ Retrieved from: http://nbuv.gov.ua/UJRN/vgtk_2014_1_8

7. Zibtsev, S. V., \& Borsuk, O. A. (2012). Okhorona lisiv vid pozhezh u sviti ta $\mathrm{v}$ Ukraini - vyklyky KhKhI storichchia ta perspektyvy rozvytku. Lisove i sadovo-parkove hospodarstvo, 1 . Retrieved from: http://nbuv.gov.ua/UJRN/licgoc_2012_1_7

8. Zuiko, V. V., Kozub, A. M., \& Mykhalevych, V. E. (2015). Suchasnyi stan i tendentsii rozvytku kosmichnykh system dystantsiinoho zonduvannia zemli providnykh krain svitu. Ozbroiennia ta viiskova tekhnika, 6(2), 51-60. https://doi.org/10.34169/2414$\underline{0651.2015 .2(6) .51-60}$

I. M. Herasymenko, O. O. Soloviova, S. V. Pron National Aviation University, Kyiv, Ukraine

\section{SOME PROSPECTIVE DIRECTIONS OF FIRE FIGHTING IN UKRAINE'S FORESTS}

An analysis of the current state of the forest fund of Ukraine has been carried out; areas with the largest and smallest forest cover were identified. Conditions for forestry in Ukraine are heterogeneous, so forests are common in the territory of the state. The largest forest areas are located in Polissya and the Carpathians. The greatest threat to forests is found to be fires, which remain a serious problem due to the large number of cases and the destruction of the area in many districts. Having analysed statistical data on fires in Ukraine, the areas with the largest number of forest fires were identified. It was found that timely detection of forest fires enables preventing their spread over large areas and the destruction of extensive forest massifs. The results of research show that aircraft is one of the most effective means of early detection and extinguishing of forest fires today. A prerequisite for ensuring the level of fire protection of forests, which corresponds to modern socio-economic requirements, is the formation of a flexible system of forest protection, capable to monitor constantly the forest polling situation, which is continuously changing in each region of Ukraine and regulate its structure, parameters and regimes of work in accordance with this situation. The formation of a flexible system of early remote detection of forest fires on the basis of existing modern unmanned aerial systems, which will be supplemented to existing aircraft manned systems, terrestrial systems and space monitoring systems, which will allow keeping track of the forest polling situation. The use of unmanned aerial vehicles to fight forest fires in a fire scheme, during a fire, after a fire that are currently performed by fire extinguishing services, as a rule, using a manned aircraft. As a result of the use of these systems during forest patrols, rapid information support is provided to the forest fire chief to determine tactics and technical methods of firefighting, as well as prompt adoption of firefighting measures in relation to a particular situation.

Keywords: aviation; monitoring; observation; fire extinguishing; unmanned aerial vehicles; interaction. 